\title{
PROCESSO DE INTERNACIONALIZAÇÃO DA ECONOMIA BRASILEIRA: CARACTERÍSTICAS DO INVESTIMENTO DIRETO EXTERNO PÓS CRISE DE 2008
}

\begin{abstract}
RESUMO
O investimento direto externo (IDE) constitui uma expressão da globalização das relações econômicas em nível mundial. Empresas buscam, de forma crescente, estabelecer plantas produtivas, além de suas fronteiras nacionais. O estoque de IDE no mundo foi multiplicado por 7 vezes nas duas últimas décadas, impulsionado principalmente pelos investimentos nos países em desenvolvimento (PED). A crise econômica mundial de 2008 impôs novo movimento do IDE em direção a estes países. O Brasil se destacou na receptação destes investimentos, cujo estoque chegou a representar mais de 10\% do IDE dos PED e 3,5\% do IDE mundial a partir de 2010. Estes números evidenciam que o país figurou entre as nações que mais receberam tais investimentos no período pós crise de 2008. Por outro lado, os investimentos externos emitidos pelo Brasil mostraram-se baixos, seja em estoque ou fluxos. O país continuou sendo grande receptor de IDE e pouco partícipe de inversões produtivas externas.
\end{abstract}

Silvio A. F. Cario ${ }^{1}$

Gabriel P. Figueiredo ${ }^{2}$

Liana Bohn ${ }^{3}$

Daniele Neuberger ${ }^{4}$

Palavras-Chave: IDE; Setores Econômicos; Desenvolvimento.

\section{PROCESS OF BRAZILIAN ECONOMY INTERNATIONALIZATION: CHARACTERISTICS OF DIRECT INVESTMENT EXTERNAL POST 2008 CRISIS}

\begin{abstract}
Foreing direct investment (FDI) is an expression of the globalization of economic relations worldwide. Companies seek, increasingly, establish production plants beyond their national borders. The stock of FDI in the world was multiplied by 7 times in the last two decades, driven mainly by investiments in developing countries. The global economic crisis of 2008 imposed new movement of FDI towards developing countries. Brazil stood out in the FDI receiving, whose stock came to hold more than $10 \%$ of the PED FDI and 3.5\% of global FDI, from the 2010. These figures show that the country was among the nations thar most received most of world FDI in the post crisis period 2008. On the other hand, foreign investiment issued by Brazil proved to be low, in stock and flows. The country remained a major recipiente of FDI and little sharer external productive investiment.
\end{abstract}

Key-Words: FDI; Economic Sectors; Development.

\footnotetext{
${ }^{1}$ Professor do Departamento de Economia e Relações Internacionais e dos Programas de Pós-Graduação em Economia e de Administração da Universidade Federal de Santa Catarina (UFSC) E-mail: fecario@yanhoo.com.br

${ }^{2}$ Doutorando do Programa de Pós-Graduação em Economia da Universidade Federal de Santa Catarina (UFSC) E-mail: gabrielfigus@hotmail.com

${ }^{3}$ Doutoranda do Programa de Pós-Graduação em Economia da Universidade Federal de Santa Catarina (UFSC) E-mail: li_bohn@hotmail.com

${ }^{4}$ Doutoranda do Programa de Pós-Graduação em Economia da Universidade Federal de Santa Catarina (UFSC)

E-mail: danineuberger@gmail.com
} 
CLASSIFICAÇÃO JEL: F21 - International Investment; Long-Term Capital Movements. I. INTRODUÇÃ̃O

O investimento direto externo (IDE) tem se constituído em uma expressão da globalização produtiva em tempos de desenvolvimento capitalista. As empresas transnacionais (ET), guiadas pelo propósito de aumentarem sua capacidade ou eficiência produtiva, estabelecem filiais fora de seus países de origem ou adquirem parte ou o todo de empresas nacionais estabelecidas nas mais distintas nações. Deste modo, o crescente movimento de internacionalização das economias abre espaço significativo para empresas estrangeiras influenciarem o processo de criação de riqueza interna nos países receptores, impactando positiva ou negativamente a região, conforme sua interação e interesses no ambiente.

Mais recentemente, o processo de globalização tem implicado também em uma intensificação do volume de investimento direto externo destinado aos países em desenvolvimento (PED). Dentre estes, a partir da década de 90, o Brasil figura como uma das principais nações receptoras, o que o fez o país mais internacionalizado da região - a entrada de IDE em relação ao PIB é superior à média mundial e à média dos países em desenvolvimento. Concomitantemente a esse fenômeno e por força do processo concorrencial, também se acompanha o estabelecimento de bases produtivas de empresas brasileiras em territórios internacionais.

Apesar dos aspectos positivos do IDE, a internacionalização das atividades produtivas e a abertura comercial implicam também a necessidade de adequação doméstica à concorrência internacional, bem como a necessidade de aproveitar as externalidades associadas aos investimentos, especialmente àqueles na forma de greenfield. Nesta via, em um sistema econômico cada vez mais interligado, torna-se fundamental a análise do IDE sobre as economias receptoras, seus efeitos ao longo do tempo e seus determinantes, para que possam ser identificados e entendidos em meios às relações internas e externas às organizações envolvidas.

Considerando estes aspectos, o objetivo deste artigo é caracterizar o movimento recente do IDE na economia brasileira, com ênfase nos anos pós-crise (a partir de 2008), em que são sentidos os primeiros sinais de ajustamento dos países à nova dinâmica de crescimento das economias internacionais. Este artigo encontra-se dividido em quatro seções, além desta introdução; na segunda, destacam-se os aspectos conjunturais do IDE no mundo, a fim de traçar seu comportamento nos últimos anos; na terceira seção busca-se a interpretação da promoção do IDE no Brasil, identificando aspectos históricos e conjunturais que balizam a compreensão dos investimentos no país; na quarta seção traz-se o panorama do IDE no Brasil, emitido e recebido em termos de fluxo, estoque, setores e subsetores econômicos; e, finalmente, na quinta seção são apresentadas as considerações finais.

\section{A CONJUNTURA ECONÔMICA E O MOVIMENTO DO IDE MUNDIAL}

As economias capitalistas atuais vivem uma nova fase de acumulação, com a intensificação de importantes processos, dentre os quais: (i) a internacionalização da produção de bens e serviços; (ii) a intensificação no fluxo de investimentos externos; (iii) o acirramento da concorrência internacional; (iv) a integração dos mercados produtivos e financeiros locais; (v) as mudanças no papel do Estado; e (vi) a emergência de novos segmentos na economia mundial. Estas transformações podem facilmente ser associadas à internacionalização das atividades das empresas transnacionais (ET's) e às mudanças em seus planos estratégicos. 
O regime de Bretton Woods, estabelecido após a $2^{\mathrm{a}}$ Guerra Mundial, gerou um ambiente favorável ao desenvolvimento das relações internacionais, de modo que a internacionalização das atividades empresariais tem gênese no pós-guerra, inicialmente em escala comercial. Com a emergência de uma nova revolução tecnológica nos anos 1970 e mediante a retomada do pensamento liberal sob uma nova roupagem nos anos 1980, intensifica-se o processo de globalização na direção das esferas produtiva e financeira (PEREIRA, 2010). Isso, somado à autonomia das políticas domésticas e à alta liquidez da economia mundial, viabilizam o renascer das economias europeias e japonesa.

Ao longo da década de 1970, também foram profundas as pressões sobre os agentes financeiros, objetivando-se a desregulamentação e a liberalização dos mercados cambiais e financeiros como forma de desafogar os gargalos gerados pelo sistema econômico. Após a recessão global de 1981-82, o cenário de instabilidade (altos níveis de inflação e juros, com câmbio flexível) exigiu adaptações por parte das grandes empresas, cuja lógica de acumulação viria a se tornar mais financeira do que produtiva, bem como mais volátil, reversível e estratégica.

No curso dos anos 1990 e 2000 os movimentos de financeirização e fragmentação internacional da produção intensificam-se e aceleram-se, como características da globalização econômica segundo novo padrão de acumulação capitalista (Chesnay, 1996 e 1998; Lacerda, 2004). Assim sendo, firma-se cada vez mais investimentos estrangeiros, compreendendo os de portfólios (reversíveis e que não se destinam ao controle efetivo de empresas), os investimentos diretos (duradouros e relativamente irreversíveis já que se passam a participar do controle das empresas, incluindo o tipo greenfield, em que a empresa investe em novas plantas) e fusões e aquisições (F\&As), como partes integrantes das ações das grandes corporações (SILVA, 2004; PERIN, 2010).

A ideia central por detrás deste fenômeno está no fato de as grandes corporações estarem se organizando, formando uma base material em uma rede internacional de negócios e redefinindo a territorialidade econômica a partir de seus interesses (SILVA, 2004). As ferramentas são os IDE's, que se refletem nos planos de produção e tecnologia, no comércio e na crescente expressão das finanças. Devido à magnitude de suas relações econômicas (produção, comércio, pesquisa e desenvolvimento - P\&D) e à inserção internacional ativa, determinam padrões de produção e comércio entre as nações. Ademais, a globalização se debruça no avanço tecnológico como eixo central do progresso (indústrias altamente intensivas em informação - knowledge intensive). Nestes casos, em que o IDE está engajado a setores intensivos em tecnologia, é possível transferir estruturas econômicas para o território local, inserindo a nação em uma dinâmica de produção mais ligada à cadeia produtiva internacional e catalisando o conhecimento tecnológico. Considerando que a capacidade de geração de inovações e tecnologia diversifica e potencializa as oportunidades econômicas, os investimentos estrangeiros podem incidir diretamente na taxa de geração de valor agregado de uma economia, assim como no rumo do desenvolvimento da nação.

Por seu turno, há casos em que o IDE direciona-se para os PEDs em busca de custos de produção menores, sobretudo relacionados à mão-de-obra barata. Neste caso, são investimentos portadores de tecnologia de uso difundido, conhecimento não complexo e de facilidade operacional nos processos produtivos. Inversões desta natureza contam com a redução dos custos de transportes, avanços tecnológicos nas telecomunicações e integração às cadeias globais de produção, permitindo além do atendimento do mercado interno desses países, alcançar diferentes praças do mercado internacional (Gereffi, 2001 e 2005).

A avaliação do comportamento internacional se dá exatamente neste sentido. Se na década de 1970 os investimentos na forma greenfield foram dominantes, a partir dos anos 1980 o IDE assume basicamente a forma de F\&A e alianças estratégicas. Na década de 1990, por sua vez, os fluxos de investimentos em portfólios e IDE predominam frente aos fluxos 
comerciais (SILVA, 2004), concomitantemente ao acirramento da concorrência oligopolista intercapitalista cruzada, via intensificação do processo de globalização, que leva o investimento estrangeiro a níveis extraordinários. No início de 1990, o estoque de IDE/PIB não ultrapassou $10 \%$ do PIB mundial, mas apresentou uma gradual elevação entre 1995 e 2002 , passando de $15 \%$ para $25 \%$, até alcançar, a partir de 2008, quase $30 \%$ do PIB mundial (UNCTAD, 2014). Isso significa que, em 15 anos, triplicou o índice de investimentos estrangeiros na economia mundial, refletindo o poder econômico e financeiro das ET's como modeladoras do processo.

No ano de 2008, a crise econômica mundial se instaurou. Como observa Bresser Pereira (2009), a crise bancária que ocorreu no centro do capitalismo, não se constituiu uma crise de balanço de pagamentos. Decorreu da concessão de empréstimos hipotecários de forma irresponsável para credores que não tinham capacidade de pagamento, frente às mudanças na conjuntura econômica. Neste contexto, contou com grande apoio para se alastrar, através da existência de sistemas financeiros desregulados - sustentados pela onda neoliberal, defensora de que os mercados são sempre eficientes e autorregulados. Com o alastramento da crise no âmbito da economia mundial, os Estados Nacionais se constituíram em tábua de salvação, fazendo intervenções anticíclicas - concedendo liquidez, subsídios e incentivos; realizando investimentos e gastos gerais; e promovendo acordos de diferentes naturezas com o setor privado.

Contudo, esta crise econômica não chegou, ainda, ao seu final. Em verdade, os anos pós 2008 tem mostrado que o movimento internacional dos investimentos externos permanece dependente das incertezas econômicas e dos riscos geopolíticos. Tais dependências implicam em uma redução dos fluxos e uma destinação maior dos recursos disponíveis aos países em desenvolvimento (PED), que não foram o epicentro da fragilidade econômica durante a crise, como em particular o Brasil.

\section{AS INTERPRETAÇÕES DA PROMOÇÃO DO IDE NO BRASIL}

Apoiando-se no trabalho de Curado e Cruz (2012) - que referencia Castro (1979) e Possas (1983) -, defende-se que os movimentos do capital produtivo dependem das condições de acumulação internacional, interna e externa. No primeiro caso, tem-se os aspectos peculiares do desenvolvimento dos países receptores e sua conjuntura em determinado momento, enquanto o marco forâneo compreende per se a situação econômica mundial, incluindo a necessidade de expansão das economias centrais. Deste diferencial surge a necessidade de avaliar o IDE no tempo histórico, levando-se em conta aspectos conjunturais e institucionais dos períodos considerados, tanto no ambiente nacional quanto internacional.

No Brasil essa distinção temporal ocorreu, recentemente, em três fases, marcadas por eventos (ou pela superação deles) que impactaram a economia do país: (i) período de alta inflação - década de 1980 e início de 1990; (ii) período de estabilização inflacionária e précrise financeira internacional - meados dos anos 1990 a 2007; (iii) crise financeira internacional e período de ajustamento das economias - 2008 até hoje. Considerando a existência de um lapso temporal entre a decisão de investir e a realização do investimento, as fases (i) e (ii), principalmente, não apresentam um determinado ano que sirva como quebra estrutural (apesar das considerações sobre 1994, por ser o ano de implementação efetiva do Plano Real).

\section{O IDE no período de alta inflação}


Arend e Fonseca (2012) observam que, desde o governo de Juscelino Kubistchek (1956-1959), ocorreu a orientação estratégica de internacionalização produtiva e de atração de recursos externos para a economia brasileira, no intuito de que a tecnologia viesse junto e a indústria resultante não seria significativamente diferente das economias da OCDE. Se isso se efetivasse, o Brasil conseguiria promover o catching up tecnológico, ainda que condicionando a trajetória de desenvolvimento à dependência externa de fluxos de capitais. Na realidade, enquanto os países avançados caminhavam para uma nova era tecnológica (microeletrônica), o Brasil ampliou sua participação na indústria intensiva em recursos naturais, distanciando-se da nova era tecnológica que se instaurava no mundo.

O reduzido fluxo de IDE para o país a partir de 1980 contribuiu para essa situação, já que foram desprezíveis os investimentos em direção ao novo paradigma tecnológico (baseado na microeletrônica, microbiologia, telecomunicações, tecnologia da informação, hardware e software, robótica, máquinas e equipamentos, novos materiais, química fỉna e derivados). Segundo os autores, a estrutura industrial brasileira mesmo contando com presença de IDE não foi capaz de ingressar no novo padrão tecno-produtivo mundial expresso pela quinta revolução tecnológica. Tal quadro, somado a outros fatores que simbolizam em um sistema inovativo imaturo, fragilidade financeira do Estado e exaustão do padrão de financiamento externo, colocou o país numa posição de falling behind que ainda perdura até os dias atuais (AREND e FONSECA, 2012, p 50).

A década perdida - anos 80 - e o período inicial dos anos 1990 foram caracterizados pela retração do ritmo de crescimento do produto e aceleração do processo inflacionário (estagflação), ajuste das contas externas por meio da contração da demanda agregada interna, instabilidade e transição política (ditadura para democracia). Neste ínterim, o cenário de instabilidade econômica e desordem do Estado, devido à crise da dívida pública, fez clamar por um novo entorno institucional e político moldado de forma a inserir o Brasil em uma dinâmica de crescimento distinta. A década de 1990, como consequência, foi marcada por reformas que visaram tornar o Brasil mais atrativo - do ponto de vista produtivo (infraestrutura) - e confiável - do ponto de vista institucional (através da regulação) - para o capital externo. Neste sentido, a abertura econômica, como estratégia, apresentava dupla perspectiva: a estabilização e o aumento da competitividade, na formação de um novo padrão de desenvolvimento da economia nacional. Pelo lado da competitividade, continuava-se esperando que o IDE trouxesse consigo um "círculo virtuoso" de "reestruturação industrial avançada", assim como resolvesse grande parte dos gargalos do financiamento. O processo de reestruturação, apesar de doloroso para alguns setores, tornaria algumas empresas exportadoras, a exemplo das indústrias alimentícia e automobilística, enquanto o elevado déficit comercial gerado pelo setor manufatureiro seria transitório, natural e reversível (BARROS e GOLDSTEIN, 1997).

O fato é que, neste período, a economia brasileira perpassou por uma situação em que o grau de incerteza no comportamento da economia foi ampliado, afetando enormemente o fluxo de IDE para o país (CURADO e CRUZ, 2008). Em texto mais recente, Curado e Cruz (2012) associam a restrição dos investimentos externos com a crise que se verificava no setor industrial, a partir do esgotamento do padrão de desenvolvimento apoiado no tripé clássico da economia brasileira - "capital privado nacional + capital privado internacional + Estado". A perda relativa de importância das atividades industriais estava, por seu turno, relacionada ao colapso do Estado brasileiro, e daí, pela perda de autonomia do mesmo como força motriz que garantia e estimulava investimentos privados no setor.

No plano externo, verificou-se o acirramento da competitividade internacional entre as empresas multinacionais, especialmente como reflexo da política do dólar forte, que implicou em uma perda da competitividade das indústrias americanas concomitantemente ao catching up tecnológico de empresas alemãs e japonesas. Soma-se a isso a mudança na estrutura 
industrial em direção ao Complexo Eletrônico - eixo dinâmico na transferência do progresso técnico pelo setor industrial -, a mundialização do capital, que implicou em crescimento dos fluxos de IDE em nível global, e o aumento da importância do IDE em F\&A, bem como a predominância dos investimentos nos setores de serviços, já em conformidade com os processos de liberalização e desregulamentação.

Diante deste ambiente interno e da nova organização internacional, a economia brasileira ficou à margem do processo de expansão dos fluxos comerciais, concentrados nos países desenvolvidos (PD). Ainda assim, é possível distinguir algumas características específicas deste processo ao longo do período, notadamente a financeirização dos IDE's, a insuficiência do volume de IDE como modo de compensar os déficits e a transição para um novo papel dos investimentos na economia do país.

Pelo lado microeconômico, as empresas (tanto nacionais quanto multinacionais) adotaram uma atitude defensiva que se deve à "permissividade do mercado interno", associada com a ausência de seletividade quanto ao investimento estrangeiro e com compromissos de desempenho, assim como pela própria política de estabilização adotada ao longo deste período (as elevadas taxas de juros reais imprimiram um caráter financeiro à atividade produtiva, servindo como instrumento para a geração de lucro). Esta "estratégia de ajuste defensivo" que combinava a diminuição de investimentos produtivos com maiores ganhos financeiros e ampliação das margens de lucro foi, sobremaneira, utilizada pelas grandes empresas brasileiras, que possuíam poder de mercado (CURADO e CRUZ, 2008).

\section{O IDE no período de estabilização inflacionária e pré-crise financeira internacional}

A década de 1990 trouxe um novo alento aos IDE's destinados ao Brasil. Para Sarti e Laplane (2002), o grande fluxo de capitais no início da década promoveu, entre alguns especialistas, a expectativa de que o país poderia retomar sua trajetória de crescimento baseado no fluxo de capitais produtivos que se expandiam na ocasião. Além disso, considerava-se que as ET's seriam fonte de inovações e crescimento na produção, com base na ampliação das exportações de produtos especializados. Contrariando esta visão, os autores acreditavam que o IDE não poderia ser visto como grande impulsionador do desenvolvimento devido ao formato que este possui no país: baixos coeficientes de capital e emprego, limitada capacidade para financiar o déficit em conta corrente, assim como para aliviar a restrição externa (porque apoiado na importação de componentes e tecnologia e tendo como alvo o mercado doméstico).

De acordo com Pereira (2010), as empresas transnacionais, supostos agentes potenciais de promoção do desenvolvimento econômico, por contarem com percentual representativo dos gastos em $\mathrm{P} \& \mathrm{D}$ em relação ao faturamento, detentoras de infraestrutura tecnológica interna, manterem vínculos ativos com universidades e institutos de pesquisa, serem proprietárias de marcas e patentes entre outros requerimentos, não se consolidaram como tal, pelo menos no quesito inovação. A aposta nesse sentido "(...) estava baseada no fato de que não havia capacidade de promover uma 'alavancagem' do crescimento a partir dos recursos (especialmente tecnológicos e financeiros) nacionais. Era a partir da abertura à competição internacional, da atração de poupança externa e dos IDE's, que se entendia estar a fonte e os mecanismos necessários para a retomada do desenvolvimento" (PEREIRA, 2010, p 178). Na verdade, a adesão completa do Brasil nessa nova dinâmica do capitalismo parecia advir de uma falta de escolha: ou ingressava na corrida democrático-tecnológico-científica ou se tornaria inexplorado. Para isso, adotou-se uma postura de atração do capital estrangeiro como forma de elevar a produção nacional a partir de recursos externos. Nesta via, a tarefa central do governo recaiu sobre a busca pela estabilidade econômica (reorientação de suas 
funções), transferindo ao setor privado a responsabilidade pela criação de alternativas de desenvolvimento.

Em meados da década, apesar do aumento do IDE no país, não se verificou um movimento ascendente da Formação Bruta de Capital Fixo, refletindo o fato de que os investimentos externos não serviram, necessariamente, para a formação de novas capacidades produtivas, mas para a transferência de propriedade do capital nacional ao estrangeiro. Observou-se, neste caso, a internacionalização da economia brasileira, concomitantemente a um processo de desnacionalização (modificação no patrimônio das empresas) e de uma assimetria entre o conteúdo exportado e importado pelas firmas. Isto decorreu em grande monta do processo de privatização em curso, que, desestimulado pela falta de dinamismo no mercado interno, implicou em um agravamento das restrições externas (SARTI e LAPLANE, 2002). Em outras palavras, ocorreram aquisições de empresas nacionais e foram relativamente escassos os investimentos em greenfield, observados nos setores automotivo e de telecomunicações (LAPLANE e SARTI, 2006). Carneiro (2002) confirma que a natureza do IDE no Brasil está predominantemente na forma de F\&A, com a estratégia de conquistar o mercado interno (market seeking) e recursos (resource based). Isso, aliado à onda de privatizações, implicou uma não criação de novas capacidades produtivas, de modo que o rumo da tecnologia nacional ficou aprisionado e seguiu dependente de uma trajetória de transferências tecnológicas vindas do capital externo (SARTI e LAPLANE, 2003).

No caso brasileiro, parece ser possível aplicar a tese de Laplane e Sarti (1997), ao defenderem a hipótese do reduzido poder de indução do IDE no crescimento econômico. Isso se confirma com Pereira (2010). Ao identificar a continuidade do padrão produtivo e o baixo nível de IDE em P\&D, torna-se visível que, apesar dos ganhos de eficiência e competitividade e da redução de gargalos na infraestrutura (notadamente nas telecomunicações), a internacionalização de alguns setores agravou a restrição externa da economia nacional. Para Arend e Fonseca (2012), neste período assistiu-se a uma elevada absorção de poupança externa que não repercutiu, como já dito, em maiores investimentos internos. Na verdade, ocorreu uma ruptura da relação histórica entre tais variáveis, com os investimentos externos se configurando como investimentos financeiros comuns dos períodos de revoluções tecnológicas, em sua fase de instalação.

A partir da segunda metade da década de 1990, o fluxo de IDE no mundo sofreu com inúmeras crises difusas pela economia mundial. Já em 1994, observa-se a crise mexicana; em 1997, o Sudeste Asiático sofreu forte desvalorização de suas moedas causando a saída em massa de capital dessas regiões; em 1998, foi a vez da Rússia, que impactou diretamente o sistema em função da moratória decretada a seus credores (DEVAI e COSTA, 2013).

Internamente, estes anos compreenderam o período de implantação do plano de estabilização econômica - Plano Real. Do ponto de vista microeconômico, a estabilização teve como um dos primeiros efeitos o aumento da produtividade e da competitividade; em nível macro, o baixo grau de investimento na indústria e o incessante saldo comercial negativo decepcionaram. Como resultado, observaram-se a desarticulação das cadeias produtivas e o abandono das atividades mais intensivas em inovação, caracterizando um processo de "especialização regressiva", baseado em vantagens naturais e em menor exposição à concorrência externa (LAPLANE e SARTI, 2006).

Ao longo dos anos 1990 o país se tornou importante receptor de IDE, especialmente em função do tamanho do mercado consumidor e da boa relação entre o Estado e o capital estrangeiro, ainda que os países asiáticos dominassem a receptação dos fluxos entre os PED. No entanto, conforme destacam Devai e Costa (2013), apesar do aumento do IDE, o estoque desses investimentos avançou em direção oposta. Enquanto no período de 1994 a 2003, o fluxo de IDE se ampliou, o estoque se retraiu, evidenciando problemas endógenos da economia nacional, especialmente relacionados com o fato de a indústria não ter avançado e o 
setor de serviços não ter gerado transbordamentos de inovações (spillovers), necessários para inserção do país no novo contexto mundial. Os ganhos de produtividade e competitividade da indústria foram evidentes com a abertura econômica, mas a sua participação no contexto internacional permaneceu estagnada (JORGE E DANTAS, 2009).

\section{O IDE na crise financeira internacional e no período de ajustamento das economias}

O movimento do IDE a partir da crise financeira internacional seguiu uma lógica contrária à observada no período de instabilidade inflacionária. Mesmo que nos últimos anos as condições internacionais fossem desfavoráveis ao investimento devido ao cenário que perdurou desde a crise de 2008, a economia brasileira esteve bastante favorável à entrada de capital produtivo internacional. Para isso, foi determinante o crescimento da economia interna, que se utilizou de políticas anticíclicas e fatores mercadológicos.

Ainda são restritos os estudos que fazem uma avaliação dos fluxos de investimento no pós-crise, de modo que o presente estudo retoma apenas interpretações gerais observadas por Prates, Cunha e Lélis (2011), que indicam a existência de um quadro interno e externo que impediu a retração dos fluxos de capitais após a crise, podendo-se destacar (i) a performance do IDE, que atingiu valores recordes, e (ii) as altas expectativas de lucro nos setores produtores de commodities, especialmente de combustíveis, extrativa mineral e nas indústrias baseadas em recursos naturais, em função da elevação dos preços no mercado internacional e do maior dinamismo do mercado interno.

Por essa via, deve ser possível relacionar os altos fluxos de capitais estrangeiros com a rápida queda de aversão ao risco, o que implicou em um mais profundo redirecionamento dos investidores globais na direção das nações menos desenvolvidas, menos impactadas pela crise. Nestas nações, os fatores internos também são fontes de atração de capitais, seja pela rápida retomada do crescimento, pelo diferencial entre os juros internos e externos (como forma de conter a inflação e o superaquecimento econômico que poderiam surgir como resposta às medidas anticíclicas) e pela própria saída bem-sucedida da crise. No caso brasileiro, todos estes elementos foram válidos, mas ainda devemos enfatizar a dimensão do mercado brasileiro e a alta dos preços das commodities como os determinantes privados para o IDE, enquanto a política-institucional (determinante do setor público) recentemente tem-se descolado das trajetórias econômicas observadas em demais países emergentes e em desenvolvimento.

\section{PANORAMA GERAL DO IDE NO BRASIL}

É possível observar pelo menos três ciclos de "liquidez" do IDE mundial ao longo das últimas décadas, conforme a Figura 1. O primeiro iniciou-se em 1991, alcançando o pico na virada do século, e o fundo em 2002-03. O segundo ciclo começou em 2003, alcançou o pico em 2007 e encerrou em 2009, apresentando menor duração cíclica. Em 2009 teve início um terceiro ciclo de fluxos de IDE na economia mundial que atingiu seu máximo em 2011, quando se reduziu novamente, encerrando em 2014. Para o ano de 2015, os fluxos de IDE já indicaram o início do ciclo seguinte. 


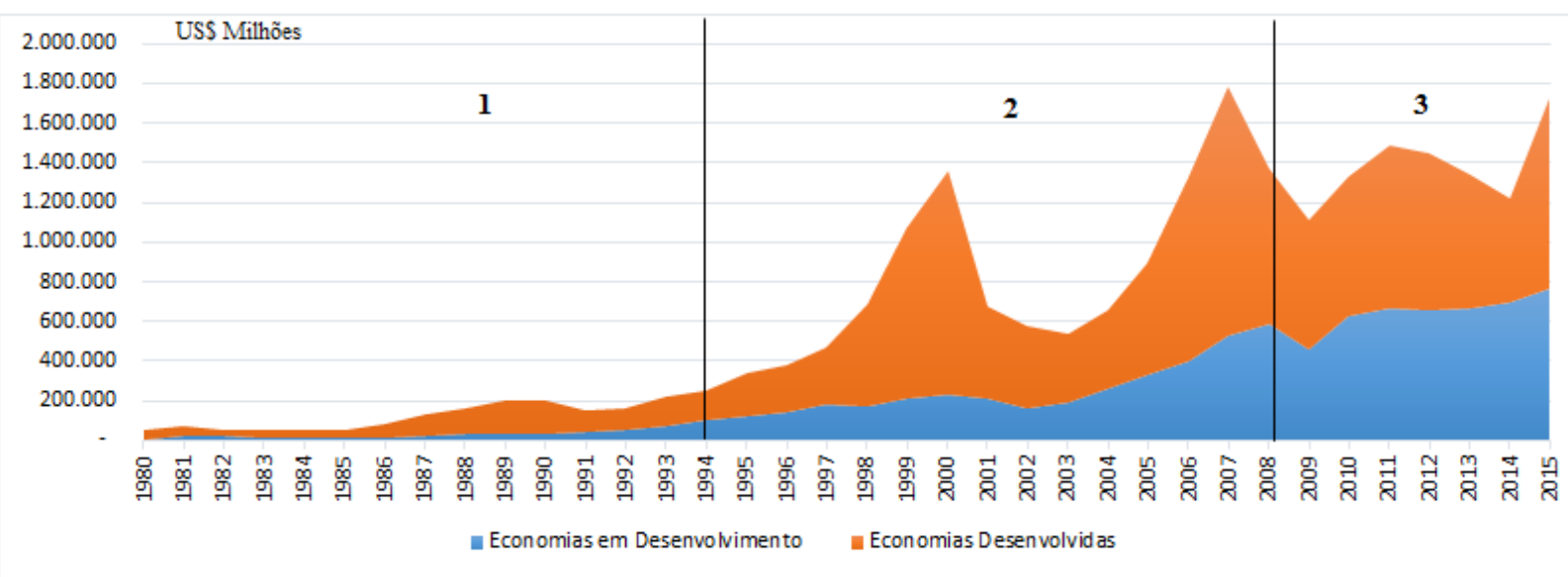

Figura 1 - Fluxo de IDE no mundo, conforme o nível de desenvolvimento e periodização considerada, em milhões de dólares

(1) Período de alta inflação; (2) Período de estabilização e pré-crise; (3) Período de crise e ajustamento Fonte: UNCTAD.

O estoque de IDE no mundo foi multiplicado por 7 vezes nas duas últimas décadas, impulsionado principalmente pelos investimentos nos PED. A Figura 1 e os dados da Tabela 1 nos permitem indagar sobre um importante fenômeno a respeito da composição dos fluxos do IDE mundial: o ciclo de liquidez do IDE que se iniciou em 2009, tem maior participação dos PED do que os da década de 1990 e dos anos 2000. A partir de 2009, o fluxo com destino aos PED alcançou mais de $40 \%$ do fluxo total. Este foi de $25 \%$ no início da década de 90 e de 32,67\% em 2003 - períodos de escassez do IDE. Nos períodos de alta liquidez do IDE estas proporções foram ainda menores para os PED. Em 2003 (final do primeiro ciclo analisado), 75\% do estoque se encontravam nos PD. Esta relação se retraiu para 64\% em 2015.

Outro fenômeno pode ser analisado. Nos períodos de ascensão do IDE, os fluxos concentraram-se nos países desenvolvidos, enquanto nos períodos de escassez do IDE o fluxo sofreu profunda redução. Entre os picos e os fundos dos ciclos analisados, a magnitude dos fluxos caiu acima dos 50\% nos PD, enquanto nos PED a redução foi de 26\% entre 2000-2003 e de $10 \%$ entre 2007-09. Isto sinaliza que os ciclos do IDE ocorreram principalmente nos PD, sendo o fluxo de IDE nos PED menos suscetíveis a volatilidade do IDE mundial.

Tabela 1 - Fluxo e Estoque de IDE no mundo, conforme nível de desenvolvimento e características do padrão econômico considerado - 1980, 1985, 1990, 1995, 2000, 2005, 2008, 2011, 2014 e 2015

\begin{tabular}{|c|c|c|c|c|c|c|c|c|c|c|}
\hline \multirow[b]{2}{*}{ Itens } & \multicolumn{4}{|c|}{ ALTA INFLAÇÃO } & \multicolumn{2}{|c|}{$\begin{array}{c}\text { INFLAÇÃO ESTÁVEL E } \\
\text { PRÉ-CRISE }\end{array}$} & \multicolumn{4}{|c|}{ CRISE E AJUSTAMENTO } \\
\hline & 1980 & 1985 & 1990 & 1995 & 2000 & 2005 & 2008 & 2011 & 2014 & 2015 \\
\hline \multicolumn{11}{|c|}{$\begin{array}{l}\text { Mundo (milhões } \\
\text { US\$) }\end{array}$} \\
\hline $\begin{array}{l}\text { Estoque } \\
\text { Fluxo }\end{array}$ & $\begin{array}{c}701.160 \\
54.400\end{array}$ & $\begin{array}{c}986.736 \\
55.835\end{array}$ & $\begin{array}{c}2.197 .768 \\
204.896\end{array}$ & $\begin{array}{c}3.566 .349 \\
341.537\end{array}$ & $\begin{array}{l}7.203 .815 \\
1.363 .215\end{array}$ & $\begin{array}{l}10.988 .575 \\
927.402\end{array}$ & $\begin{array}{c}14.979 .376 \\
1.489 .732\end{array}$ & $\begin{array}{c}20.441 .729 \\
1.566 .839\end{array}$ & $\begin{array}{c}24.626 .455 \\
1.318 .470\end{array}$ & $\begin{array}{c}24.983 .214 \\
1.762 .155\end{array}$ \\
\hline \multicolumn{11}{|c|}{$\begin{array}{c}\text { Economias } \\
\text { Desenvolvidas } \\
(\%)\end{array}$} \\
\hline $\begin{array}{l}\text { Estoque } \\
\text { Fluxo }\end{array}$ & $\begin{array}{l}58,00 \\
86,36\end{array}$ & $\begin{array}{l}62,46 \\
74,77\end{array}$ & $\begin{array}{l}76,71 \\
83,07\end{array}$ & $\begin{array}{l}76,02 \\
64,35\end{array}$ & $\begin{array}{l}76,02 \\
82,54\end{array}$ & $\begin{array}{l}73,64 \\
60,97\end{array}$ & $\begin{array}{l}70,38 \\
52,88\end{array}$ & $\begin{array}{l}65,09 \\
52,17\end{array}$ & $\begin{array}{l}63,31 \\
39,59\end{array}$ & $\begin{array}{l}64,07 \\
54,62\end{array}$ \\
\hline \multicolumn{11}{|c|}{$\begin{array}{c}\text { Economias em } \\
\text { Desenvolvimento } \\
(\%)\end{array}$} \\
\hline $\begin{array}{l}\text { Estoque } \\
\text { Fluxo } \\
\end{array}$ & $\begin{array}{l}42,00 \\
13,60 \\
\end{array}$ & $\begin{array}{l}37,54 \\
25,20 \\
\end{array}$ & $\begin{array}{l}23,21 \\
16,89 \\
\end{array}$ & $\begin{array}{l}23,67 \\
34,48 \\
\end{array}$ & $\begin{array}{l}23,18 \\
17,03 \\
\end{array}$ & $\begin{array}{l}24,02 \\
35,60 \\
\end{array}$ & $\begin{array}{l}27,00 \\
39,31 \\
\end{array}$ & $\begin{array}{l}31,27 \\
42,77 \\
\end{array}$ & $\begin{array}{l}33,74 \\
52,98 \\
\end{array}$ & $\begin{array}{l}33,52 \\
43,39 \\
\end{array}$ \\
\hline \multicolumn{11}{|c|}{$\begin{array}{c}\text { Países em } \\
\text { Transição* (\%) }\end{array}$} \\
\hline $\begin{array}{l}\text { Estoque } \\
\text { Fluxo }\end{array}$ & $\begin{array}{l}0,00 \\
0,04\end{array}$ & $\begin{array}{l}0,00 \\
0,03\end{array}$ & $\begin{array}{l}0,08 \\
0,04\end{array}$ & $\begin{array}{l}0,31 \\
1,17\end{array}$ & $\begin{array}{l}0,80 \\
0,42\end{array}$ & $\begin{array}{l}2,35 \\
3,43\end{array}$ & $\begin{array}{l}2,62 \\
7,81\end{array}$ & $\begin{array}{l}3,64 \\
5,06\end{array}$ & $\begin{array}{l}2,94 \\
4,28\end{array}$ & $\begin{array}{l}2,41 \\
1,99\end{array}$ \\
\hline
\end{tabular}

* Sudeste Europeu, CIS e Georgia. 
Em termos de participação no fluxo de IDE mundial, observa-se que, desde a década de 80, os PED vêm aumentando sua participação, com concomitante perda de participação dos PD. Esta tendência foi acentuada a partir da crise de 2008: enquanto que em 2007 a participação dos PED no IDE mundial era de 28,2\%, já em 2008 este percentual passou para $39,3 \%$. Ao mesmo tempo, a participação dos PD era de $67 \%$ em 2007, caindo para 52,9\% em 2008. Em 2014 verifica-se, pela primeira vez na série analisada, que a participação dos PED ultrapassou a dos PD: 55,5\% do fluxo de IDE mundial foram direcionados aos primeiros, enquanto que 40,6\% destinaram-se aos últimos. Em 2015, porém, haja vista o aparente início de um novo ciclo de liquidez de investimentos, a situação se reverteu novamente, com a maior parte dos fluxos de IDE sendo direcionados aos PD, conforme pode ser visto na Figura 2 .

Nos últimos anos o Brasil ganhou importância como destino do IDE mundial. Entretanto, trinta anos antes, sua participação no total do IDE mundial era superior à do período inflacionário, ao período de estabilização, ou de acentuação do processo de privatização no país. Esta tendência também foi observada em outros PED. A partir dos anos 2000 tomou forma um movimento de desconcentração do IDE dos países desenvolvidos na direção dos menos desenvolvidos. Por outra via, como é o caso brasileiro, o formato do IDE associado a estes valores se expressou principalmente na forma de transferências patrimoniais, haja vista que poucos foram os investimentos efetivamente realizados.

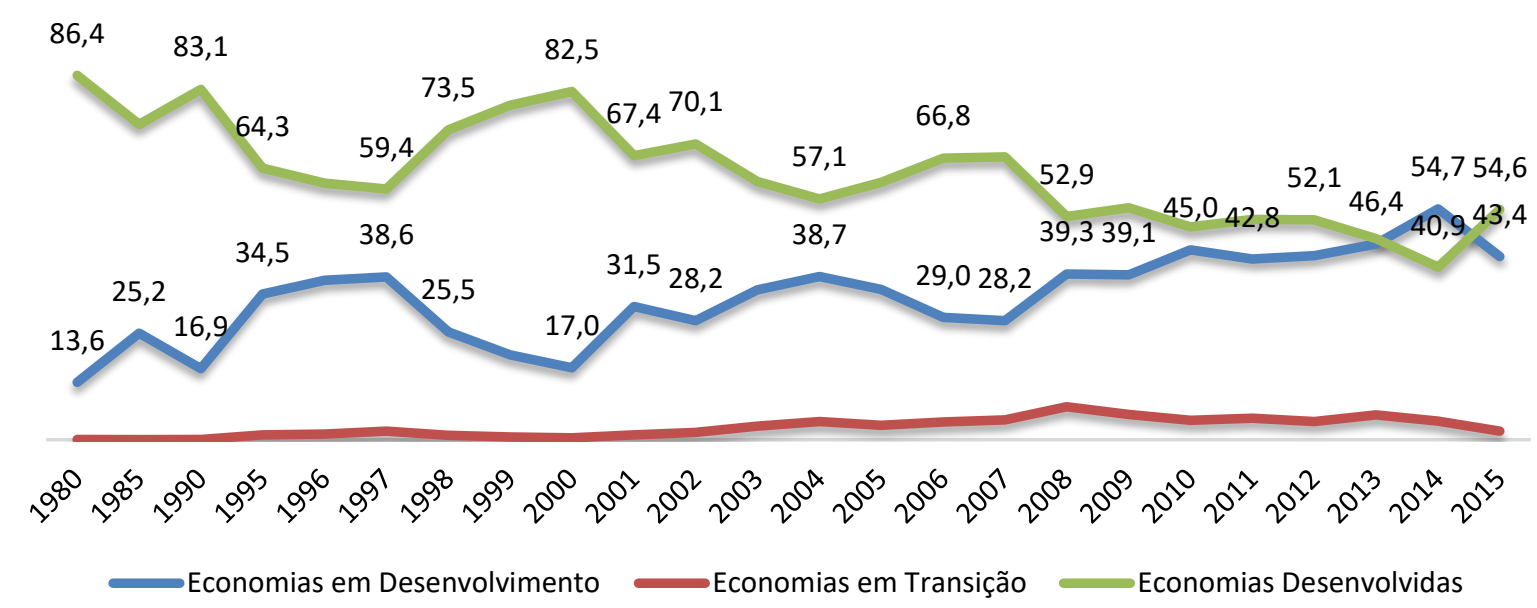

Figura 2 - Participação no fluxo de IDE mundial, conforme nível de desenvolvimento, 1980, 1985, 1990, 1995-2015.

Fonte: UNCTAD (2016).

De acordo com dados da UNCTAD, durante os anos 1990 até 2009, o estoque de IDE em território brasileiro mal ultrapassou 8\% do estoque dos PED. A partir de 2010 ocorreu uma inflexão neste comportamento, com o Brasil chegando a deter mais de $10 \%$ do estoque de IDE dos PED, ou 3,5\% do total dos IDE do mundo. Fato é que a duração desta ampliação foi curta, já que em 2012 a participação começou novamente a decair, atingindo 6\% dos PED e menos de $2 \%$ do IDE mundial em 2015. Isso é um indicativo de que a situação econômica interna do país começou a colocá-lo em uma dinâmica distinta das demais nações em desenvolvimento, muito embora o movimento do capital produtivo seja redirecionado com intensidades distintas.

Em comparação ao fluxo de IDE na Argentina e no Chile, o brasileiro parece ser o mais instável. Durante a década de 80 até o início dos anos 90, a participação do IDE 
brasileiro entre os PED sofreu drástica redução, mantendo-se em considerável ascensão até a virada do século - em virtude da abertura financeira do país --, diminuindo novamente até a crise de 2008 e crescendo a partir de então, principalmente até o ano de 2012. A trajetória a partir de 2012 foi de redução da participação no IDE dos PED, refletindo as incertezas econômicas internas e no cenário internacional.

No que se refere ao fluxo de IDE mundial, a participação do IDE brasileiro seguiu as mesmas tendências apresentadas em relação ao IDE dos PED, porém, com flutuações mais acentuadas. Se em 2007, ano imediatamente anterior à crise, a participação do IDE brasileiro no IDE dos PED era de 6,5\% chegando a 14,3\% em 2011, e reduziu para 8,5\% em 2015. Em relação ao IDE mundial, a participação brasileira era de $1,8 \%$ em 2007 , passou para $6,1 \%$ em 2011 e para 3,7\% em 2015, como pode ser observado na Figura 3.

Em 2015, os fluxos de IDE aumentaram 38\% em relação a 2014, atingindo US\$ 1,76 trilhão, maior nível desde a crise de 2008-2009, porém ainda cerca de $10 \%$ inferior ao nível observado no ano de 2007. Para 2016, espera-se que os fluxos de IDE sejam reduzidos em 10 a $15 \%$, tendo em vista a fragilidade da economia global e a queda persistente da demanda agregada. Adicionalmente, a recessão esperada do IDE pode ser acentuada pelos riscos geopolíticos e regionais. A médio prazo, porém, espera-se a retomada dos fluxos: para 2017, projeta-se crescimento em relação a 2016 e, para 2018, estes devem ultrapassar US\$1,8 trilhão (UNCTAD, 2016).

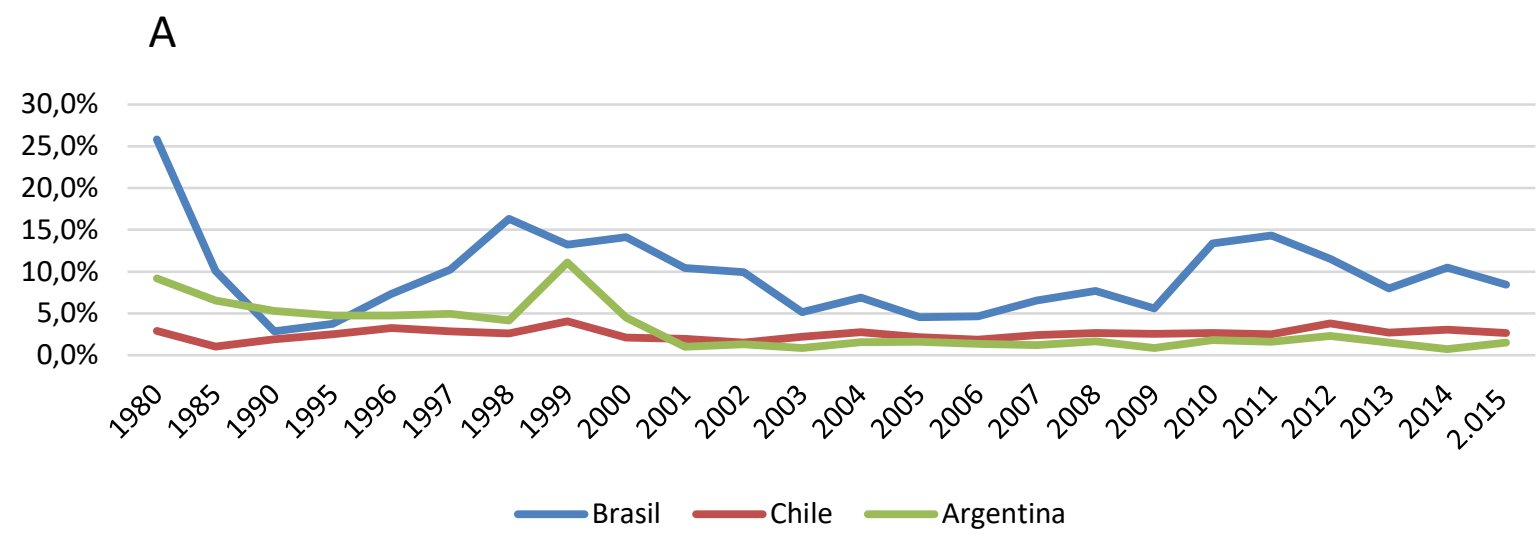

B

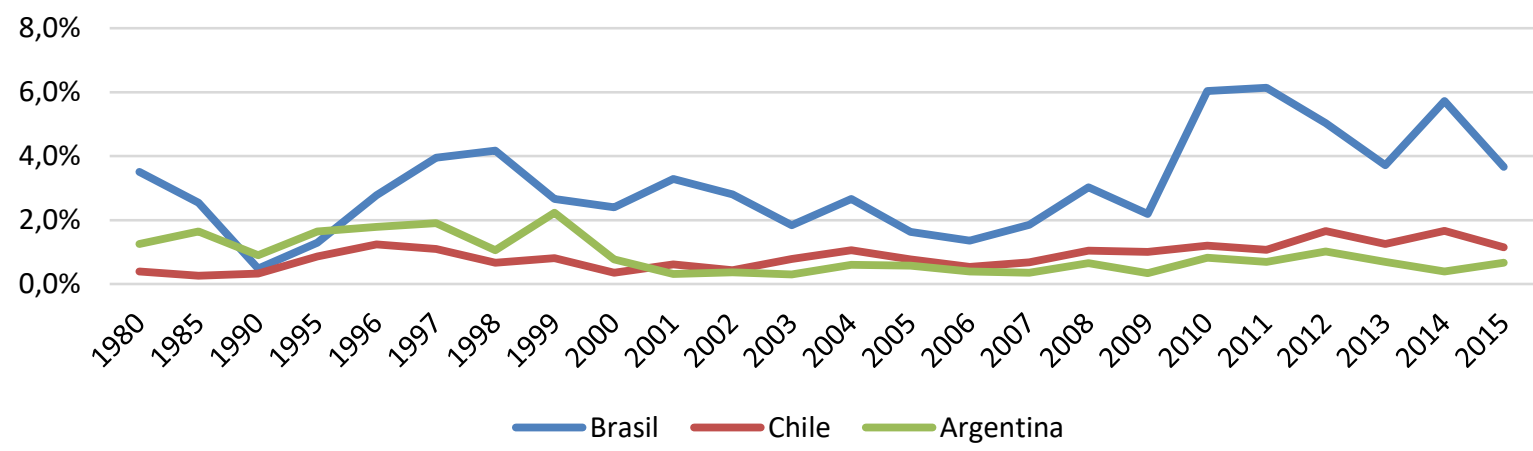

Figura 3 - Participação do Brasil, Chile e Argentina no fluxo de IDE dos PED (A) e em nível mundial (B) - 1980, 1985, 1990, 1995-2015, (em \%).

Fonte: UNCTAD (2016).

Para os próximos anos, estima-se que o Brasil continue figurando entre os cinco principais receptores do IDE mundial, muito embora em 2015 os fluxos destinados ao país 
tenham declinado. Essa inserção brasileira na dinâmica externa do IDE deveria beneficiar vários segmentos da economia nacional, ainda que seja necessário avaliar as estratégias de atuação das grandes ETs, com vistas ao mercado interno ou na produção para o mercado externo. Este investimento poderá orientar o Brasil em um novo padrão de competitividade ou se limitar à busca de mercados e recursos, com assimetrias tecnoprodutivas, comerciais e patrimoniais entre o Brasil e outros PED. Além disso, torna-se um problema para o país se o crescimento for restringido pela insustentabilidade do balanço de pagamentos, diante da elevada elasticidade de importação quando ocorre o crescimento da economia nacional.

\section{Evolução do IDE emitido e recebido pela economia brasileira}

Os primeiros anos da década de 1990 foram desfavoráveis ao Brasil no que se refere ao IDE recebido e, principalmente, ao IDE emitido. No início da década, o estoque de IDE emitido superava o recebido pela economia brasileira, enquanto que, entre 1995-2000, o país ganhou destaque como destino do IDE mundial (de 1,34\% para 1,63\%) e entre os PED (de $5,67 \%$ para $7,44 \%)$.

Este movimento se deve aos programas de atração de capital internacional e às privatizações, em consonância com uma fase próspera de investimentos estrangeiros no plano mundial, concentrado pelos PD. A partir dos anos 2000, foi crescente a formação de estoque de IDE na economia brasileira, pouco abaixo da dinâmica mundial e dos PED. O período coincide com o término do ciclo de IDE mundial iniciado na década de 1990 (2000-03: retração dos fluxos de IDE), e início de um novo ciclo que se encerra em 2009 (2003-07: expansão, 2008-09: retração). Neste segundo ciclo de IDE, o Brasil foi beneficiado, assim como grande parte dos PED. A partir de 2009 uma nova fase de IDE paira sobre a economia mundial, com o Brasil se mantendo como destino importante dos fluxos de investimento (em 2015, o país deteve $3,67 \%$ dos investimentos mundiais e $8,45 \%$ entre as inversões estrangeiras dos PED).

Com relação aos investimentos emitidos pela economia brasileira, seus valores foram extremamente baixos, seja em estoque ou fluxos. Houve uma redução na participação mundial de 6,90\% em 1980 para 0,72\% em 2015 (de 54,47\% para 3,43\% entre os PED). O que fica mais evidente, porém, é a redução da emissão de IDE brasileiro no ano de 2015, que caiu quase a metade do observado em 2014, e colocando o país em uma trajetória completamente distinta da observada pela média mundial, bem como pelos PED: a participação do IDE brasileiro no mundial era de $1,29 \%$ em 2014 , caindo para $0,72 \%$ em 2015 , e a participação no IDE emitido pelos PED era de 6,55\% em 2014, reduzindo para 3,43\% em 2015 (UNCTAD).

O estoque recebido de IDE no Brasil situou-se em US\$ 486 bilhões em 2015, mais de duas vezes superior ao emitido, de US\$ 181 bilhões, mas com expressiva queda em relação a 2014. Em relação aos valores do início da década o estoque interno foi multiplicado por 4, e o estoque externo por 3,5, indicando um maior nível de internacionalização da economia brasileira, bem como revelando um processo de inserção mais ativa do país como investidor e receptor de IDE a partir de meados de 2000.

A origem do IDE recebido pela economia brasileira

No início do presente século (antes do último boom de IDE mundial), os cinco maiores investidores no Brasil eram os EUA, Espanha, Holanda, França e as Ilhas Cayman, com 60\% do estoque de IDE em território nacional, conforme a Tabela 2. 
Tabela 2 - Estoque dos 12 Principais Países Proprietários de IDE Ingressado no Brasil, 2000, 2010, 2012 e 2014 (em US\$ milhões e em \%).

\begin{tabular}{|c|c|c|c|c|c|c|c|c|}
\hline \multirow[b]{2}{*}{ Total } & \multicolumn{2}{|c|}{2000} & \multicolumn{2}{|c|}{2010} & \multicolumn{2}{|c|}{2012} & \multicolumn{2}{|c|}{2014} \\
\hline & 103.015 & $(\%)$ & 587209 & $(\%)$ & 617384 & $(\%)$ & 531445 & $(\%)$ \\
\hline EUA & 24.5 & $24 \%$ & 109700 & $19 \%$ & 125440 & $20 \%$ & 111715 & $21 \%$ \\
\hline Países Baixos & 11.055 & $11 \%$ & 14868 & $3 \%$ & 13298 & $2 \%$ & 71352 & $13 \%$ \\
\hline Espanha & 12.253 & $12 \%$ & 85421 & $15 \%$ & 71256 & $12 \%$ & 59483 & $11 \%$ \\
\hline Reino Unido & 1.488 & $1 \%$ & 41635 & $7 \%$ & 46875 & $8 \%$ & 36739 & $7 \%$ \\
\hline França & 6.931 & $7 \%$ & 30674 & $5 \%$ & 36907 & $6 \%$ & 31602 & $6 \%$ \\
\hline Japão & 2.468 & $2 \%$ & 29004 & $5 \%$ & 32063 & $5 \%$ & 26820 & $5 \%$ \\
\hline Alemanha & 5.11 & $5 \%$ & 30350 & $5 \%$ & 24489 & $4 \%$ & 18192 & $3 \%$ \\
\hline Luxemburgo & 1.034 & $1 \%$ & 13198 & $2 \%$ & 15112 & $2 \%$ & 14223 & $3 \%$ \\
\hline Canadá & 2.028 & $2 \%$ & 14443 & $2 \%$ & 14593 & $2 \%$ & 10565 & $2 \%$ \\
\hline Chile & 228 & $0 \%$ & 3747 & $1 \%$ & 4717 & $1 \%$ & 5706 & $1 \%$ \\
\hline Austrália & 78 & $0 \%$ & 6540 & $1 \%$ & 5365 & $1 \%$ & 5649 & $1 \%$ \\
\hline Ilhas Cayman & 6.225 & $6 \%$ & 2423 & $0 \%$ & 4782 & $1 \%$ & 4219 & $1 \%$ \\
\hline Demais & 29 & & $35 c$ & & $36^{\circ}$ & & $25 \%$ & \\
\hline
\end{tabular}

Fonte: Banco Central do Brasil.

A partir de 2003, uma nova frente de expansão do IDE mundial fortaleceu as posições da Holanda e da Espanha como segunda e terceira nações com maior investimento no Brasil. Neste período, o Japão também se destacou e as Ilhas Cayman deixaram de ser um dos principais investidores. Em termos de região, ganhou importância durante os anos 2000 o investimento europeu e asiático, enquanto que, em termos de nível de desenvolvimento dos países investidores, no período pós-crise ocorreu o aumento para mais de $50 \%$ do IDE originário dos PD. Outros países que se destacaram com investimentos no Brasil foram a Alemanha, a Holanda, Luxemburgo, Canadá, Austrália e Chile. No último ano de análise, destacaram-se como maiores investidores: EUA, Holanda e Espanha (com 45\% do estoque de IDE brasileiro), seguidos do Reino Unido, França, Japão, Alemanha, Luxemburgo, Canadá e Chile. Em conjunto, os investimentos destes 10 países representaram $72 \%$ do estoque de IDE em território nacional.

\section{Divisão setorial do IDE brasileiro}

A divisão setorial do estoque de IDE no Brasil sofreu profundas alterações ao longo dos últimos anos, conforme a Tabela 3. Em 1995, o estoque de IDE se concentrava, primordialmente, na indústria $(67 \%)$, uma parcela consideravelmente menor no setor de serviços $(31 \%)$ e o restante $(2 \%)$ no setor primário. Com o processo de privatizações e abertura comercial, esta configuração se inverteu drasticamente em favor do setor de serviços, que teve sua participação aumentada para $63 \%$ do total do IDE no ano de 2000, enquanto que a participação da indústria reduziu para $34 \%$ (quase a metade do observado cinco anos antes).

Ao longo dos anos 2000, porém, a participação da indústria voltou a crescer e ganhou destaque o setor primário. Em 2010, estes setores detiveram, respectivamente, $40 \%$ e $16 \%$ do estoque de IDE presente no Brasil. Concomitantemente, o setor de serviços teve sua participação reduzida para 44\%. A configuração setorial do IDE no Brasil no período póscrise implica, portanto, em uma desconcentração/diversificação dos investimentos do setor de 
serviços para os outros setores da economia. No ano de 2014 a divisão permanecia próxima à observada em 2010, com destaque maior, porém, ao setor de serviços, em detrimento do setor primário.

Tabela 3 - Divisão setorial do IDE no Brasil, 1995, 2000, 2010, 2012 e 2014 (em milhões de US\$ e em \%).

\begin{tabular}{|c|c|c|c|c|c|c|c|c|c|c|}
\hline \multirow{2}{*}{ Atividade Econômica } & \multicolumn{2}{|c|}{1995} & \multicolumn{2}{|c|}{2000} & \multicolumn{2}{|c|}{2010} & \multicolumn{2}{|c|}{2012} & \multicolumn{2}{|c|}{2014} \\
\hline & US\$ & $\%$ & US\$ & $\%$ & US\$ & $\%$ & US\$ & $\%$ & US\$ & $\%$ \\
\hline $\begin{array}{l}\text { Agricultura, pecuária e } \\
\text { extrativa mineral }\end{array}$ & 924 & 2.2 & 2401 & 2.3 & 92775 & 15.8 & 72030 & 11.7 & 63061 & 12 \\
\hline Indústria & 27907 & 67 & 34725 & 34 & 236376 & 40.2 & 264100 & 43 & 207594 & 39 \\
\hline Serviços & 12863 & 31 & 65887 & 63 & 258058 & 44 & 281254 & 46 & 260789 & 49 \\
\hline TOTAL & 416 & & 10301 & & 587209 & & 617384 & & 531445 & \\
\hline
\end{tabular}

Fonte: Banco Central do Brasil.

O ganho da importância do setor primário nos fluxos e no estoque de IDE é um fenômeno aparentemente novo na economia brasileira, segundo Relatório do BACEN (2015). Entre os anos de 2001 a 2005, 54,4\% dos fluxos foram destinados ao setor de serviços, 38,3\% para a indústria e 7,3\% para o setor primário - divisão já desconcentrada em relação à estrutura do estoque formada na virada do século (ano 2000). Este movimento ganhou corpo ao longo da década. Para os anos de 2006 a 2009, o destino dos fluxos foi de 45,8\% para os serviços, $36 \%$ à indústria, e 18,2\% ao primário. Além do setor primário, a indústria também apresentou-se como segmento atrativo do IDE, enquanto o setor de serviços manteve-se, ainda como segmento de maior representatividade das inversões forâneas.

A antiga configuração do IDE no Brasil surpreende no que diz respeito às diferenças em relação ao padrão mundial. Em média, era bem maior o proporcional de IDE na indústria brasileira, principalmente em detrimento dos serviços. Apesar das mudanças, a nova configuração ainda carrega um profundo caráter industrial e, no que concerne ao setor primário, também se observa uma ultrapassagem com relação à média mundial, na qual os estoques de IDE estão voltados aos serviços em uma proporção consideravelmente maior.

Segmentos receptores do IDE na economia brasileira

Como é possível observar na Tabela 4, em meio às alterações, os principais segmentos receptores do IDE, para os anos recentes (2010-2014) no setor de serviços foram: $\left(1^{\circ}\right)$ Serviços Financeiros e Atividades Auxiliares; $\left(2^{\circ}\right)$ Telecomunicações; $\left(3^{\circ}\right)$ Comércio, exceto Veículos, $\left(4^{\circ}\right)$ Eletricidade, Gás e Outras Utilidades e $\left(5^{\circ}\right)$ Atividades Imobiliárias. Em conjunto, representaram 74\% dos fluxos de IDE para o setor em 2014 e $36 \%$ do IDE brasileiro. Neste quadro, o segmento de Telecomunicações, foi o único intensivo em tecnologia que recentemente representou posição de destaque, enquanto Atividades de Informática e TI, que também se encontram no vértice da tecnologia, foram alvos de baixo investimento.

Tabela 4 - Principais segmentos receptores do IDE no setor de serviços do Brasil, 2010-2014 (em milhões de US\$ e em \%).

\begin{tabular}{|c|c|c|c|c|c|c|c|c|c|c|}
\hline \multirow{3}{*}{ Serviços } & \multicolumn{2}{|c|}{2010} & \multicolumn{2}{|c|}{2011} & \multicolumn{2}{|c|}{2012} & \multicolumn{2}{|c|}{2013} & \multicolumn{2}{|c|}{2014} \\
\hline & US\$ & $\%$ & US\$ & $\%$ & US\$ & $\%$ & US\$ & $\%$ & US\$ & $\%$ \\
\hline & 258.058 & 44 & 265.525 & 45 & 281.254 & 46 & 261.605 & 46 & 260.789 & 49 \\
\hline $\begin{array}{l}\text { Serviços Financeiros e Atividades } \\
\text { Auxiliares }\end{array}$ & 99.207 & 17 & 86.309 & 15 & 88.305 & 14 & 78.041 & 14 & 79.732 & 15 \\
\hline Telecomunicacões & 40.646 & 7 & 53.612 & 9 & 48.734 & 8 & 44.871 & 8 & 39.798 & 7 \\
\hline
\end{tabular}




\begin{tabular}{|c|c|c|c|c|c|c|c|c|c|c|}
\hline Comércio, exceto Veículos & 27.220 & 5 & 28.680 & 5 & 33.350 & 5 & 28.039 & 5 & 35.032 & 7 \\
\hline $\begin{array}{l}\text { Eletricidade, Gás e Outras } \\
\text { Utilidades }\end{array}$ & 29.146 & 5 & 29.005 & 5 & 28.672 & 5 & 27.672 & 5 & 23.526 & 4 \\
\hline Atividades Imobiliárias & 12.120 & 2 & 12.920 & 2 & 17.090 & 3 & 17.710 & 3 & 14.080 & 3 \\
\hline $\begin{array}{l}\text { Seguros, Resseguros, Previdência } \\
\text { Complementar, Planos de Saúde }\end{array}$ & 10.161 & 2 & 13.200 & 2 & 16.502 & 3 & 15.160 & 3 & 16.453 & 3 \\
\hline $\begin{array}{l}\text { Atividades Sedes de Empresa, } \\
\text { Consultoria em Gestão de } \\
\text { Empresas }\end{array}$ & 3.946 & 1 & 4.787 & 1 & 6.807 & 1 & 9.130 & 2 & 9.851 & 2 \\
\hline $\begin{array}{l}\text { Serviços de Tecnologia da } \\
\text { Informática }\end{array}$ & 3.866 & 1 & 4.259 & 1 & 5.463 & 1 & 5.162 & 1 & 3.839 & 1 \\
\hline Construção de Edifícios & 6.273 & 1 & 4.866 & 1 & 4.727 & 1 & 3.497 & 1 & 4.288 & 1 \\
\hline Obras de Infraestrutura & 3.224 & 1 & 3.394 & 1 & 4.159 & 1 & 3.297 & 1 & 2.710 & 1 \\
\hline
\end{tabular}

Fonte: Banco Central do Brasil (2016).

Conforme a Tabela 5, no setor industrial foram destaques: $\left(1^{\circ}\right)$ Bebidas (10\% do

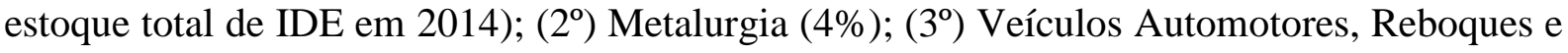
Carrocerias (3\%); $\left(4^{\circ}\right)$ Produtos Alimentícios (3\%); e, $\left(5^{\circ}\right)$ Produtos Químicos (3\%). Estes foram responsáveis por $25 \%$ do estoque de IDE no país e por $62 \%$ dos investimentos estrangeiros industriais. Em relação ao ano de 1995 (início do boom dos investimentos estrangeiros na economia mundial), as indústrias Química e Automobilística possuíam desempenho superior em relação à Metalurgia. Entre 1995-2000, ganharam importância os segmentos de Fabricação de Alimentos e Bebidas, Máquinas e Equipamentos e Fabricação de Material Eletrônico, Aparelhos e Equipamentos para Comunicação. Durante os anos 2000, observou-se a continuidade desta tendência de ganho de importância do IDE nos referidos segmentos.

Tabela 5 - Principais segmentos receptores do IDE no setor industrial do Brasil, 2010-2014 (em milhões de US\$ e em \%).

\begin{tabular}{|c|c|c|c|c|c|c|c|c|c|c|}
\hline \multirow{3}{*}{ Indústria } & \multicolumn{2}{|c|}{2010} & \multicolumn{2}{|c|}{2011} & \multicolumn{2}{|c|}{2012} & \multicolumn{2}{|c|}{2013} & \multicolumn{2}{|c|}{2014} \\
\hline & US\$ & $\%$ & US\$ & $\%$ & US\$ & $\%$ & US\$ & $\%$ & US\$ & $\%$ \\
\hline & 236.376 & 40 & 238.637 & 40 & 264.100 & 43 & 243.332 & 42 & $207 . .594$ & 39 \\
\hline Bebidas & 52.405 & 9 & 63.815 & 11 & 79.003 & 13 & 70.028 & 12 & 55.504 & 10 \\
\hline Metalurgia & 27.572 & 5 & 21.972 & 4 & 23.768 & 4 & 22.012 & 4 & 21.422 & 4 \\
\hline $\begin{array}{l}\text { Veículos Automot., Reboques e } \\
\text { Carroc. }\end{array}$ & 28.686 & 5 & 25.536 & 4 & 24.232 & 4 & 22.452 & 4 & 18.455 & 3 \\
\hline Produtos Alimentícios & 14.660 & 2 & 14.578 & 2 & 17.983 & 3 & 15.698 & 3 & 18.346 & 3 \\
\hline Produtos Químicos & 25.447 & 4 & 22.881 & 4 & 25.904 & 4 & 23.033 & 4 & 18.104 & 3 \\
\hline Máquinas e Equipamentos & 11.185 & 2 & 11.615 & 2 & 11.491 & 2 & 10.974 & 2 & 9.833 & 2 \\
\hline Produtos do Fumo & 13.815 & 2 & 15.144 & 3 & 18.430 & 3 & 12.853 & 2 & 9.339 & 2 \\
\hline $\begin{array}{l}\text { Produtos Farmoquímicos e } \\
\text { Farmácia }\end{array}$ & 8.931 & 2 & 8.218 & 1 & 9.673 & 2 & 9.648 & 2 & 8.338 & 2 \\
\hline $\begin{array}{l}\text { Produtos de Borracha e Material } \\
\text { Plástico }\end{array}$ & 6.951 & 1 & 7.621 & 1 & 7.092 & 1 & 7.848 & 1 & 7.087 & 1 \\
\hline Produtos de Metal & 6.706 & 1 & 7.530 & 1 & 7.448 & 1 & 7.261 & 1 & 3.217 & 1 \\
\hline
\end{tabular}

Tabela 6 - Principais segmentos receptores do IDE no setor primário do Brasil, 2010-2014 (em milhões de US\$ e em \%).

\begin{tabular}{|c|c|c|c|c|c|c|c|c|c|c|}
\hline \multirow{3}{*}{$\begin{array}{c}\text { Agricultura, Pecuária e } \\
\text { Extrativa Mineral }\end{array}$} & \multicolumn{2}{|c|}{2010} & \multicolumn{2}{|c|}{2011} & \multicolumn{2}{|c|}{2012} & \multicolumn{2}{|c|}{2013} & \multicolumn{2}{|c|}{2014} \\
\hline & US\$ & $\%$ & US\$ & $\%$ & US\$ & $\%$ & US\$ & $\%$ & US\$ & $\%$ \\
\hline & 92.775 & 16 & 86.432 & 15 & 72.030 & 12 & 68.808 & 12 & 63.061 & 12 \\
\hline $\begin{array}{l}\text { Extração de Petróleo e Gás } \\
\text { Natural }\end{array}$ & 49.580 & 8 & 46.243 & 8 & 36.367 & 6 & 35.647 & 6 & 33.901 & 6 \\
\hline Extração de Minerais Metálicos & 27.329 & 5 & 23.820 & 4 & 18.767 & 3 & 14.308 & 2 & 9.666 & 2 \\
\hline Apoio à Extração de minerais & 1.334 & 0 & 1.496 & 0 & 2.124 & 0 & 4.481 & 1 & 8.688 & 2 \\
\hline Agricultura, Pecuária e Serviços & 3.561 & 1 & 5.216 & 1 & 6.754 & 1 & 5.338 & 1 & 4.851 & 1 \\
\hline Extração Minerais não-Metálicos & 9002 & 2 & 8.029 & 1 & 6.800 & 1 & 6.821 & 1 & 4.138 & 1 \\
\hline Produção Florestal & 1.966 & 0 & 1.624 & 0 & 1.212 & 0 & 2.209 & 0 & 1.812 & 0 \\
\hline Pesca e Aquicultura & 3 & 0 & 3 & 0 & 4 & 0 & 5 & 0 & 5 & 0 \\
\hline
\end{tabular}

Fonte: Banco Central do Brasil (2016).

No setor primário, conforme a Tabela 6, os estoques entre 2010-14 se concentraram na Extração de Petróleo e Gás Natural (6\% dos investimentos totais e 54\% do setor primário), seguido pela Extração de Minerais Metálicos (2\% dos investimentos totais e 15\% do setor 
primário) e Atividades de Apoio à Extração de Minerais (14\% do estoque de IDE no setor). Agricultura, Pecuária e seus Serviços representaram 8\% dos investimentos totais. Até 1995, o segmento que se destacava era o da Extração de Minerais Metálicos, de modo que, entre 1995-2000, ocorreu uma inversão nas posições entre os dois segmentos dominantes, com o estoque de IDE na Extração de Petróleo superando o de Minerais Metálicos. Entre 2000 e 2005, o IDE para Petróleo manteve a liderança e, a partir de 2005, foi substancial o crescimento do IDE na Extração de Minerais Metálicos. A partir de 2010, ganharam participação como destino do IDE as Atividades de Apoio à Extração de Minerais, em detrimento da Extração de Petróleo e Gás Natural e da Extração de Minerais Metálicos.

Destino do IDE emitido pela economia brasileira

Nos anos 2000 o Brasil retomou posição como investidor internacional, deixando de perder participação na emissão de IDE. A partir de 2006, os fluxos emitidos colocaram o país em posição de destaque, ganhando participação no IDE mundial. Porém, a emissão não superou, em taxa ou magnitude, a receptação de IDE. No início dos anos 2000 - auge do ciclo de IDE dos PD - o estoque emitido mal superava os US\$ 50 trilhões e, em 2005 (próximo do auge do segundo ciclo), o estoque chegou a quase US\$ 80 trilhões, crescendo substancialmente no período pós crise e chegando próximo de US\$270 trilhões em 2014. Em 2015, no entanto, tendo em vista a recessão atravessada pelo país, o estoque reduziu seu valor para cerca de US\$259,3 trilhões.

O estoque de IDE brasileiro na Europa foi multiplicado por 35 durante a década, crescendo principalmente nos últimos dez anos. Para a América Latina, houve redução da participação no estoque, apesar de seu considerável aumento em termos absolutos. Nestes termos, para o ano de 2015, os 10 principais destinos do estoque do IDE brasileiro foram, em ordem de importância: Ilhas Cayman (com 22,6\% do estoque), Áustria (14,9\%), Holanda (13,7\%), Ilhas Virgens Britânicas (10,3\%), Bahamas (8,2\%), Espanha, Estados Unidos, Argentina, Uruguai e Peru (que somam $11,7 \%$ do estoque de IDE).

Divisão setorial e segmentos do IDE emitido pela economia brasileira

A análise da divisão setorial do IDE brasileiro no exterior no início dos anos 2000 foi inviabilizada por mudanças na classificação dos dados, mas anos mais recentes (2008-2015) puderam ser analisados. A distribuição setorial do IDE brasileiro no exterior diverge da estrutura produtiva e de IDE em território nacional. Neste caso, existe uma maior participação do investimento no setor de serviços, em detrimento do setor primário e da indústria (valores de $66 \%, 18 \%$ e $16 \%$, respectivamente, em 2015), conforme a Tabela 7.

Tabela 7 - Divisão setorial do IDE no Brasil, 2008, 2010, 2012-2015 (em milhões de US\$ e em \%)

\begin{tabular}{|c|c|c|c|c|c|c|c|c|c|c|c|c|}
\hline \multirow{2}{*}{ Atividade Econômica } & \multicolumn{2}{|c|}{2008} & \multicolumn{2}{|c|}{2010} & \multicolumn{2}{|c|}{2012} & \multicolumn{2}{|c|}{2013} & \multicolumn{2}{|c|}{2014} & \multicolumn{2}{|c|}{2015} \\
\hline & US\$ & $\%$ & US\$ & $\%$ & US\$ & $\%$ & US\$ & $\%$ & US\$ & $\%$ & US\$ & $\%$ \\
\hline $\begin{array}{l}\text { Agricultura, pecuária e extrativa } \\
\text { mineral }\end{array}$ & 35.324 & 31 & 52.855 & 31 & 61.936 & 25 & 72.967 & 27 & 51.966 & 19 & 47.164 & 18 \\
\hline Indústria & 14.666 & 13 & 27.046 & 16 & 44.702 & 18 & 50.748 & 19 & 43.391 & 16 & 40.516 & 16 \\
\hline Serviços & 63.765 & 56 & 89.165 & 53 & 140.533 & 57 & 149.207 & 55 & 174.475 & 65 & 171.615 & 66 \\
\hline TOTAL & 113.755 & & 169.066 & & 247.172 & & 272.921 & & 269.832 & & 259.294 & \\
\hline
\end{tabular}

Fonte: Banco Central do Brasil (2016).

Ao longo dos últimos anos (2008-2015), a dinâmica de investimento do setor primário perdeu participação, sobretudo, para os investimentos no setor de serviços, que tinham participação de 56\% em 2008 passando para 66\% em 2015. Neste período, o estoque de IDE 
no exterior foi multiplicado por 2,3. Os estoques de IDE no setor de serviços e na indústria foram multiplicados por 2,7 e 2,8, respectivamente, enquanto que o setor primário teve seu estoque de IDE no exterior multiplicado por apenas por 1,3.

Tabela 8 - Principais segmentos receptores do IDE brasileiro no setor de serviços, 2009, 2011, 2013-2015 (em milhões de US\$ em \%)

\begin{tabular}{|c|c|c|c|c|c|c|c|c|c|c|}
\hline \multirow{3}{*}{ Serviços } & \multicolumn{2}{|c|}{2009} & \multicolumn{2}{|c|}{2011} & \multicolumn{2}{|c|}{2013} & \multicolumn{2}{|c|}{2014} & \multicolumn{2}{|c|}{2015} \\
\hline & US\$ & $\%$ & US\$ & $\%$ & US\$ & $\%$ & US\$ & $\%$ & US\$ & $\%$ \\
\hline & 70.152 & 53,0 & 100.065 & 51,9 & 149.207 & 54,7 & 174.475 & 64,7 & 171.615 & 66,2 \\
\hline Serviços Financeiros & 41.278 & 31,2 & 69.580 & 36,1 & 105.261 & 38,6 & 123.380 & 45,7 & 124.221 & 47,9 \\
\hline $\begin{array}{l}\text { Atividades de Sedes de Empresas e de } \\
\text { Consultoria }\end{array}$ & 6.622 & 5,0 & 4.731 & 2,5 & 7.539 & 2,8 & 10.256 & 3,8 & 11.968 & 4,6 \\
\hline $\begin{array}{l}\text { Atividades Profissionais, Científicas e } \\
\text { téc. }\end{array}$ & 6.780 & 5,1 & 6.266 & 3,2 & 7.251 & 2,7 & 8.499 & 3,1 & 8.425 & 3,2 \\
\hline Comércio, exceto Veículos & 1.870 & 1,4 & 4.470 & 2,3 & 7.627 & 2,8 & 7.663 & 2,8 & 6.563 & 2,5 \\
\hline $\begin{array}{l}\text { Atividades Auxiliares de Serviços } \\
\text { Financeiros }\end{array}$ & 5.047 & 3,8 & 4.704 & 2,4 & 3.796 & 1,4 & 3.884 & 1,4 & 3.787 & 1,5 \\
\hline Obras de Infraestrutura & 724 & 0,5 & 1.729 & 0,9 & 3.355 & 1,2 & 3.547 & 1,3 & 2.993 & 1,2 \\
\hline $\begin{array}{l}\text { Serviços de Escritório e Prestados a } \\
\text { Empresas }\end{array}$ & 3.494 & 2,6 & 2.402 & 1,2 & 3.430 & 1,3 & 3.194 & 1,2 & 2.347 & 0,9 \\
\hline Serviços Pessoais & 1.069 & 0,8 & 1.377 & 0,7 & 2.643 & 1,0 & 2.648 & 1,0 & 2.233 & 0,9 \\
\hline Atividades Imobiliárias & 448 & 0,3 & 1.103 & 0,6 & 1.355 & 0,5 & 2.112 & 0,8 & 2102 & 0,8 \\
\hline $\begin{array}{l}\text { Aluguéis não-Imob. e Gestão de Ativos } \\
\text { Intangíveis }\end{array}$ & 167 & 0,1 & 1.262 & 0,7 & 1.021 & 0,4 & 1.374 & 0,5 & 321 & 0,1 \\
\hline
\end{tabular}

Fonte: Banco Central do Brasil (2016).

Dentro do setor de serviços (onde se encontra mais de $66 \%$ do estoque de IDE) ganharam destaque, nos anos recentes: $\left(1^{\circ}\right)$ Serviços Financeiros (concentrado com $72 \%$ do estoque de serviços) em detrimento de $\left(2^{\circ}\right)$ Atividades de Sedes de Empresas e de Consultoria, $\left(3^{\circ}\right)$ Atividades Profissionais, Científicas e Técnicas e $\left(4^{\circ}\right)$ Comércio, exceto Veículos. O estoque destes três segmentos não superou $16 \%$ do estoque no setor. $\mathrm{Na}\left(5^{\circ}\right)$ posição se encontram as Atividades Auxiliares de Serviços Financeiros (com aproximadamente $2 \%$ do estoque no setor). Esta hierarquia não apresentou profunda alteração durante a década, apesar da mudança de posição das atividades no ranking do setor de serviços, conforme a Tabela 8.

No setor industrial, no início dos anos 2000, os principais segmentos eram (i) Fabricação de Coque, Refino de Petróleo, Elaboração de Combustíveis Nucleares e Álcool, com 29\% do estoque, (ii) Produção de Minerais Não-Metálicos (20\% do estoque), (iii) Máquinas e Equipamentos (11\%), (iv) Veículos Automóveis, Reboques e Carrocerias (7\%), (v) Metalurgia/Produtos de Metal, e (vi) Produtos Alimentícios. Ao longo da década foram profundas as alterações no destino industrial do IDE brasileiro, com destaque para a: $\left(1^{\circ}\right)$ Metalurgia e $\left(2^{\circ}\right)$ Bebidas, que conjuntamente compreendem mais de $55 \%$ do estoque industrial no exterior, segundo as informações contidas na Tabela 9. Apesar de sua baixa magnitude, o IDE brasileiro industrial aparenta ser mais diversificado que os outros setores econômicos. Para o ano de 2015, a configuração industrial do IDE foi, portanto: $\left(1^{\circ}\right)$ Metalurgia (29,5\% do IDE industrial e 4,6\% do total), $\left(2^{\mathrm{a}}\right)$ Bebidas $(25,8 \%$ e $4 \%$, respectivamente), $\left(3^{\circ}\right)$ Produtos Minerais Não-Metálicos $(19,4 \%$ e $3 \%)$ e $\left(4^{\circ}\right)$ Produtos Alimentícios (10,3\% e 1,6\%).

Tabela 9 - Principais segmentos industriais receptores do IDE brasileiro - 2009, 2011, 2013 2015 (em milhões de US\$ e em \%).

\begin{tabular}{|c|c|c|c|c|c|c|c|c|c|c|}
\hline \multirow{3}{*}{ Indústria } & \multicolumn{2}{|c|}{2009} & \multicolumn{2}{|c|}{2011} & \multicolumn{2}{|c|}{2013} & \multicolumn{2}{|c|}{2014} & \multicolumn{2}{|c|}{2015} \\
\hline & US\$ & $\%$ & US\$ & $\%$ & US\$ & $\%$ & US\$ & $\%$ & US\$ & $\%$ \\
\hline & 20407 & 15,4 & 31219 & 16,2 & 50748 & 18,6 & 43391 & 16,1 & 40516 & 15,6 \\
\hline Metalurgia & 4119 & 3,1 & 14730 & 7,6 & 15698 & 5,8 & 12544 & 4,6 & 11938 & 4,6 \\
\hline Bebidas & 6584 & 5,0 & 1417 & 0,7 & 13435 & 4,9 & 11619 & 4,3 & 10469 & 4,0 \\
\hline Produtos Minerais Não-Metálicos & 1756 & 1,3 & 6171 & 3,2 & 9903 & 3,6 & 9578 & 3,5 & 7877 & 3,0 \\
\hline Produtos Alimentícios & 4236 & 3,2 & 4697 & 2,4 & 5854 & 2,1 & 4825 & 1,8 & 4166 & 1,6 \\
\hline Manutenção, Reparação e Instalação de Máquinas & 312 & 0,2 & 370 & 0,2 & 928 & 0,3 & 404 & 0,1 & 1585 & 0,6 \\
\hline
\end{tabular}




\begin{tabular}{|c|c|c|c|c|c|c|c|c|c|c|}
\hline Produtos Têxteis & 250 & 0,2 & 329 & 0,2 & 301 & 0,1 & 404 & 0,1 & 1585 & 0,6 \\
\hline Máquinas e Equipamentos & 253 & 0,2 & 348 & 0,2 & 400 & 0,1 & 351 & 0,1 & 691 & 0,3 \\
\hline Outros Equipamentos de Transporte & 977 & 0,7 & 768 & 0,4 & 562 & 0,2 & 642 & 0,2 & 652 & 0,3 \\
\hline Veículos Automotores, Reboques e Carrocerias & 569 & 0,4 & 606 & 0,3 & 629 & 0,2 & 575 & 0,2 & 424 & 0,2 \\
\hline Produtos de Borracha e de Material Plástico & 439 & 0,3 & 599 & 0,3 & 527 & 0,2 & 552 & 0,2 & 347 & 0,1 \\
\hline Produtos Químicos & 501 & 0,4 & 611 & 0,3 & 1535 & 0,6 & 204 & 0,1 & 328 & 0,1 \\
\hline
\end{tabular}

Fonte: Banco Central do Brasil (2015).

Tabela 10 - Principais segmentos do setor primário receptores do IDE brasileiro - 2009, 2011, 2012, 2014 e 2015 (em milhões de US\$ e em \%).

\begin{tabular}{|c|c|c|c|c|c|c|c|c|c|c|}
\hline \multirow{3}{*}{$\begin{array}{l}\text { Agricultura, pecuária e extrativa } \\
\text { mineral }\end{array}$} & \multicolumn{2}{|c|}{2009} & \multicolumn{2}{|c|}{2011} & \multicolumn{2}{|c|}{2012} & \multicolumn{2}{|c|}{2014} & \multicolumn{2}{|c|}{2015} \\
\hline & US\$ & $\%$ & US\$ & $\%$ & US\$ & $\%$ & US\$ & $\%$ & US\$ & $\%$ \\
\hline & 41855 & 31,6 & 61649 & 32,0 & 61936 & 25,1 & 51966 & 19,3 & 47164 & $\overline{18,2}$ \\
\hline Extração de minerais metálicos & 39947 & 30,2 & 49164 & 25,5 & 42806 & 17,3 & 32439 & 12,0 & 21821 & $\overline{8,4}$ \\
\hline Extração de petróleo e gás natural & 1432 & 1,1 & 8554 & 4,4 & 12348 & 5,0 & 16582 & 6,1 & 22755 & $\overline{8,8}$ \\
\hline $\begin{array}{l}\text { Agricultura, pecuária e serviços } \\
\text { relacionados }\end{array}$ & 126 & 0,1 & 802 & 0,4 & 1354 & 0,5 & 1627 & 0,6 & 1514 & 0,6 \\
\hline
\end{tabular}

Fonte: Banco Central do Brasil (2015),

No setor primário, o segmento líder foi Extração de Petróleo e Gás Natural, seguido de Extração de Minerais Metálicos, com $48 \%$ e $46 \%$ do estoque de IDE no setor primário, respectivamente, como expressa a Tabela 10. Chama a atenção o aumento da participação da Extração de Petróleo e Gás Natural (que passou de 1,1\% de participação no total do IDE emitido em 2009 para 8,8\% em 2015), em detrimento da participação da Extração de Minerais Metálicos (que foi reduzida de 30,2\% em 2009 para 8,4\% em 2015).

\section{CONSIDERAÇÕES FINAIS}

No plano internacional, o IDE atinge proporções recordes em relação ao PIB dos países (mais de 30\% do PIB mundial em 2008 e 2009), tornando-se fundamental estudar esta temática. São observados três ciclos de liquidez do IDE mundial a partir dos anos 90, sendo que o segundo (de 2003 a 2009) carregou consigo um acentuado movimento de desconcentração do IDE, na direção dos PED. Estes investimentos foram menos voláteis que os IDE que ocorreram nos PD. A partir de 2009 iniciou-se uma nova fase de liquidez do IDE, ainda mais direcionada aos PED. Este fenômeno tende a gerar profundos efeitos sobre as estruturas produtivas e econômicas das nações envolvidas. Em 2014, pela primeira vez foi possível observar que os fluxos destinados aos PED foram superiores aos destinados aos PD. Em 2015, 33,5\% do estoque de IDE se encontravam nos PED (e 43,4\% dos fluxos).

A partir de meados dos anos 2000, foi possível observar que o Brasil ganhou importância, não apenas como receptor, mas também como emissor de IDE, apesar de o estoque emitido pouco superar $40 \%$ do recebido. Durante o período pós-crise, o país se destacou entre as cinco nações mais promissoras para o IDE, ao mesmo tempo em que o IDE brasileiro no exterior foi multiplicado e se internacionalizou com vigor. Em comparação com os países vizinhos Chile e Argentina, o Brasil também se destacou nos últimos anos, por apresentar uma dinâmica superior tanto em relação ao IDE recebido pelos PED, quanto em relação ao IDE mundial, sobretudo no período pós-crise de 2008.

Internamente, nos últimos 15 anos, foi intensa a reestruturação da origem dos investimentos. Em 1995 destacavam-se os EUA, Alemanha, Japão, França e Reino Unido como maiores investidores. Este quadro se alterou nos anos 2000, ao incluir Holanda, Espanha, Ilhas Cayman e Canadá. Nos últimos anos, esta estrutura se fortificou e a dinâmica 
brasileira passou a estar mais atrelada com a Europa, e em alguma escala com a Ásia, em detrimento de países do Norte e latino-americanos. Os EUA, apesar de perderem participação relativa, ainda apresentaram o maior estoque de IDE na economia brasileira, (21\% do IDE), seguido pela Holanda, Espanha, Reino Unido, França e Japão.

Também ocorreram profundas mudanças na divisão setorial do estoque no Brasil. Entre 1995 e 2000, ampliou-se a participação do setor de serviços em detrimento da indústria, aproximando a estrutura ao padrão internacional. Nos anos 2000 foi a indústria que se destacou, enquanto o setor primário teve sua importância desencadeada. A partir da crise, o destino do IDE foi visivelmente a indústria, chegando a $39 \%$ do estoque de investimento em 2014. O setor de serviços ainda manteve $49 \%$ e o setor primário, $12 \%$. Com estas alterações os segmentos receptores do IDE destacados no período pós-crise foram: (i) Serviços Financeiros, (ii) Bebidas, (iii) Telecomunicações, (iv) Comércio, (v) Eletricidade e Gás, (vi) Metalurgia, (vii) Fabricação e Montagem de Veículos Automotores e (viii) Produtos Alimentícios, segmentos de serviços e da indústria. No setor primário, os fluxos e estoques concentram-se em dois segmentos: Extração de Minerais Metálicos e Extração de Petróleo e Serviços.

Uma forte mudança também foi observada no destino do IDE brasileiro, que passou das Ilhas Cayman, Virgens Britânicas e Bahamas para países da Europa, ao mesmo tempo que se mantem os investimentos nos EUA e outros países da América Latina. O estoque de investimento emitido apresentou ser mais diversificado que o recebido. Os principais países destinos do IDE brasileiro no pós-crise (2015) foram: Ilhas Cayman, Áustria, Holanda, Ilhas Virgens Britânicas e Bahamas. Considera-se para esse conjunto de países, motivações além dos objetivos de ganhos em paraísos fiscais, mas também outras como de natureza produtivas, acesso a mercados representativos, interesses estratégicos de longo prazo, facilidades fiscais e financeiras, etc. Apesar de a indústria liderar o crescimento dos estoques, existe uma predominância dos investimentos nos setores primário e terciário, especialmente concentrados em (i) Extração de Minerais Metálicos, (ii) Petróleo e Gás Natural, (iii) Serviços Financeiros, e (iv) Atividades Profissionais, Científicas e Técnicas.

O período pós-crise, portanto, foi favorável ao Brasil tanto para a receptação como emissão do IDE, sobretudo até o ano de 2014. Entretanto, mesmo diante das mudanças nas características do IDE, grande parte dele busca o mercado consumidor nacional, de modo que os investimentos estrangeiros não foram suficientes para promover o crescimento econômico junto às cadeias produtivas globais. Contudo, o país continua dependentes do capital estrangeiro e das inovações repassadas de fora do país, dada a significativa inserção externa na economia doméstica. Expectativas ficam, que ao caminhar conjuntamente com a dinâmica econômica global, venha se ter um processo virtuoso de crescimento econômico, para compensar os prejuízos, especialmente no que concerne à exposição de maior vulnerabilidade diante das flutuações econômicas internacionais e das assimetrias comerciais e patrimoniais.

\section{REFERÊNCIAS BIBLIOGRÁFICAS}

AREND, M.; FONSECA, P. C. D. Brasil (1955-2005): 25 anos de catching up, 25 anos de falling behind. Revista de Economia Política, v. 32, n. 1 (126), p. 33-54, Jan/Mar 2012.

BARROS, J. R. M.; GOLDENSTEIN, L. A avaliação do processo de reestruturação industrial brasileiro. Revista de Economia Política, v. 17, n. 2, Abr/Jun 1997.

BRESSER PEREIRA, L. C. A crise financeira de 2008. Revista de Economia Política, vo. 29, no. 1 (113), pp. 133-149, Jan/Mar/2009.

CARNEIRO, R. Desenvolvimento em crise: a economia brasileira no último quarto do século XX. São Paulo: Editora UNESP, IE - UNICAMP, p. 309-356, 2002. 
CASTRO, A. C. As empresas estrangeiras no Brasil (1860-1913). São Paulo: Zahar Editores, 1979.

CHESNAY, F. A mundialização do capital. SP: Xamã, 1996.

CHESNAY, F. A mundialização financeira: gênese, custos e riscos. Xamã, 1998.

CURADO, M.; CRUZ, M. Investimento Direto Externo e Industrialização no Brasil. Revista de Economia Contemporânea, Rio de Janeiro, v 12, n 3, p 399-431, Set/Dez 2008.

CURADO, M; CRUZ, M. Investimento Direto Externo no Brasil: uma análise para o período de alta inflação. Economia e Sociedade, Campinas, v. 21, n. 2 (45), p. 275-300, Ago/2012.

DEVAI, O. C.; DALLA COSTA, A. M. Investimento Direto Externo no Brasil no processo de Desenvolvimento Econômico Brasileiro: uma análise do período de estabilidade inflacionária sem crescimento (1994-2003). XVI ANPEC SUL 2013. Anais. Curitiba, 2013.

GEREFFI, G. Las cadernas productivas como marco analítico para la globalización. Problemas del Desarrollo, v. 32, n. 125, p. 9 -37, abr-jun, 2001.

GEREFFI, G. The global economy: organization, governance and development. In: SMELSER, N.; SWEDBERG, R. (eds). Handbook of Economic Sociology. Princeton University Press and Russel Sage Foundation, 2005.

JORGE, M. F.; DANTAS, A. T. Investimento Estrangeiro Direto, Transbordamento e Produtividade: um estudo sobre ramos selecionados da indústria no Brasil. Revista Brasileira de Inovação, Rio de Janeiro, v. 8, n. 2, p. 481 - 514, Jul/Dez 2009.

LACERDA, A. C. Globalização e investimento estrangeiro no Brasil. SP: Saraiva, 2004.

LAPLANE, M.; SARTI, F. Prometeu acorrentado: o Brasil na indústria mundial no início do século XXI. In: CARNEIRO, R. (Org) A supremacia dos mercados e a política econômica do Governo Lula. São Paulo: Fapesp - Unesp, 2006.

LAPLANE, M., SARTI, F. Investimento direto estrangeiro e a retomada do crescimento sustentado nos anos 90. Economia e sociedade, Revista do Instituto de Economia da Unicamp, n. 8, Jun. 1997.

PEREIRA, A.J. Inovação, aprendizado e desenvolvimento econômico: uma abordagem evolucionária sobre os impactos do comportamento inovativo das grandes empresas estrangeiras na indústria de transformação brasileira (1998-2005). Tese (Doutorado em Economia) - Programa de Pós-Graduação em Economia - Universidade Federal do Rio Grande do Sul, 2010.

PERIN, F. S. Processo de internacionalização de empresas brasileiras: Um estudo sobre o Investimento Direto Externo, 2001-2008. Monografia (Graduação em Ciências Econômicas) - Departamento de Economia - Universidade Federal de Santa Catarina Florianópolis, UFSC, 2010.

POSSAS, M. L. Multinacionais e industrialização no Brasil. In: BELLUZO, L. G. M.; COUTINHO, R. Desenvolvimento capitalista no Brasil: ensaios sobre a crise. 2 Ed. São Paulo: Brasiliense, 1983.

PRATES, D.M.; CUNHA, A.M.; LÉLIS, M.T.C. O Brasil e a crise financeira global: avaliando os canais de transmissão nas contas externas. Revista de Economia Contemporânea, RJ, v.15, n. 1, Jan/Abr 2011.SARTI, F.; LAPLANE, M. L. O investimento direto estrangeiro e a internacionalização da economia brasileira nos anos 1990. Economia e Sociedade, Campinas, v. 11, n. 1 (18), p 63-94, 2002. 
SARTI, F.; LAPLANE, M. L. O investimento direto estrangeiro e a internacionalização da economia brasileira nos anos 90. In: LAPLANE, M.; COUTINHO, R.; HIRATUKA, C. (Orgs.) Internacionalização e desenvolvimento da indústria no Brasil. SP: Ed. Unesp, p 11-58, 2003.

SILVA, L. A. Brasil, China e Índia: O Investimento Direto Externo nos anos noventa. Tese (Doutorado em Economia) - Instituto de Economia Campinas: UNICAMP, 2004.

UNCTAD. United Nations Conference on Trade and Development. Estatísticas. Disponível em: http://unctad.org/en/Pages/statistics.aspx

UNCTAD. World Investment Report 2014. United Nations, New York/Geneva, Mimeo, 2014.

UNCTAD. World Investment Report 2016. United Nations, New York/Geneva, Mimeo, 2016. 